\title{
Media as Medium in Colombian Education: How Media and ICT are Changing Communication and the Curriculum in the School*
}

\author{
Los medios como medio de educación en Colombia: \\ Cómo los medios y las TICs estan cambiando la \\ comunicación y el currículo escolar
}

\author{
Carolina Rodríguez Bohórquez \\ Normal Superior Maria Montessori Bogotá, Colombia \\ E-mail: cjcarolrb@yahoo.es \\ Nicolas Hine \\ Assistant Profesor, School of Computing \\ University of Dundee, UK \\ E-mail: nhine@computing.dundee.ac.uk
}

\begin{abstract}
We describe how secondary school students are engaged in designing school newspapers, broadcasting radio shows and using ICT in classrooms as opportunities for communication and learning. The central goal in this project was to set up the school dynamics where radio, newspaper, television, video, images and ICT's play the role of additional inputs and increase the community interest in literacy. We present some practical initiatives that demonstrate the possibilities of media literacy based activities in a public school in Bogota, Colombia
\end{abstract}

Key Words: Communication in school, newspaper and radio in classrooms, use of ICT's in EFL learning, collaborative learning.

\section{Resumen}

Describimos cómo los estudiantes de escuela secundaria se motivaron a diseñar el periódico escolar, a emitir desde la radio en la escuela y a usar las nuevas tecnologías en el aula de clase como oportunidades para la comunicación y el aprendizaje. El objetivo central en este proyecto fue establecer dinámicas en la escuela donde la radio, el periódico, la televisión, el video, las imágenes y las TIC desempeñaran el papel de recursos adicionales para aumentar el interés de la comunidad por la educación. Finalmente presentamos algunas iniciativas prácticas para demostrar posibles actividades de aprendizaje basadas en alfabetización en medios en una escuela pública en Bogotá, Colombia

Palabras Claves: Comunicación en la escuela, el periódico y la radio en el aula de clase, uso de TIC en el aprendizaje de Inglés, aprendizaje colaborativo.

* $\quad$ Received 18-07-07 Accepted 21-08-09 


\section{Introduction}

Over the last few years some teachers have become increasingly concerned about the impact that mass media can have on students, generating a variety of different responses. Some of these are very positive but others are more negative and ridicule or destroy the positivity of other teachers. In practice, it is important to recognise the difficulties and seek to work around those to realise the benefits. In this context, it is important to think about education in a new way, where the school, the teachers and their practices take into account the relationships that their students have with their culture and environments. More than just to transmit knowledge, information and skills, teacher should work towards preparing students for transformations with responsibility, as Barbero (2000) states, to form persons capable of learning to learn and to adapt to a changing world.

Within the walls of a school many great achievements can happen and many important stories that can be told. The school is a community where stories and narratives take place. Each child, each girl, each boy, brings with them a book of events, of life experiences, that affects the way he/she learns. Stories are the means by which we communicate within communities (Emler 2001). Read E Miller (in Schank 1990) also remind us that they are also essential as a mechanism for organising knowledge in memory. More than this, storytelling is a creative process that enables young people to express themselves (individually and collaboratively) by bringing together information into an engaging and coherent argument (Bruner 1986). Stories are the basis for case based (and therefore reusable) memories (Schank 1995) and are, as a result, essential for healthy cognitive development. Stories are therefore, not only vehicles for meaningful social interactions but also for learning. Learning through stories happens best when accompanied by socializing through stories.
One of the challenges that teachers face daily is to recognize those life stories, to face the students' realities and with them try to give the opportunity to reinterpret their environment. But the perennial question, the permanent concern would be - What for? What opportunities does education open for students? For example, why try to teach a foreign language to a student who has fundamental concerns about living in very basic conditions where food, health and the economy prevent their families from thinking about a future where the English language can be useful?

In practice, there is often little connection between the curriculum, the application of knowledge, and the realities of the lives of the students. If these connections are made, however, students can understand theories, contents, rules and use what they have learned in real communicative situations. However, universities and teacher training courses don't generally assume this perspective, so they don't teach how to "seduce" the students with materials and exercises adjusted to their real interests and inquiries.

\section{The pedagogical context}

San Agustin School in the South of Bogota (locality 18, Rafael Uribe Uribe) is immersed in the realities described above. More than 3,800 students attend the school each day, where the responsibility of teachers is to connect the students with learning and knowledge in such a way that not only promotes reflection but even the possibility of social change. When this happens, real possibilities occur for the $1^{\text {st }}$ and $2^{\text {nd }}$ socioeconomical level of youth to take advantage of the hope of education; the education that, as Freire (1972) stated, would liberate them, to get them ready to face the world outside when they finish their studies. This happens when real channels 
of communication and exercising of responsibility in the teaching/learning processes occur that place the students in their environment, becoming increasingly conscious of situations around them and allowing them to assume responsibilities for the transformation of their communities using not only media but also a range of ICT.

Students are surrounded by many messages carried by a variety of different media, mediated by a host of different technologies. The challenge is for students to critical evaluate the messages conveyed by these media so that they can wisely make decisions and become responsible and creative members of society. This challenge requires innovation and a multi-disciplinary approach from the schools. In the case of San Agustin School, the decision was taken to explore the possibilities of teaching kids how to produce media, as a means of understanding how to encode meaning within different media, and as a consequence, how to decode the meaning within the media around them. In this way, stereotypes can be challenged and realities faced and addressed. This strategy recognised the reality that students live in a global world, they need to comprehend the messages of this global world, so they need to think as citizens of a global world, and bringing the best of the global ideas, values and possibilities to bear on local realities.

For these students, "Literacy is not the reading and writing words in and of themselves, as if the reading and writing of words did not imply another reading, anterior to and simultaneous with the first -- the reading of reality itself." Freire and Macedo (1987). It's helpful to analyze then the connection between literacy and environment according to whether it reinforces existing social relationships, or introduces a new set of cultural practices that promote democratic and emancipatory changes and real social transformations.

So this story is one where a pedagogical innovation took place. Since 2001, in San
Agustín school, this multidisciplinary approach and the new relationships between students arose from reflection on the teaching of English. The school started to change; because of the waves, because of the voices and because of the goals in the dreams that the teachers had. Since 2002, a group of 40 children and young people from both primary and secondary school revolutionized the whole school. This process that took place is described below.

\section{The Promise of Printed Words}

In the middle of the $20^{\text {th }}$ century Freinet in his work "Modernizar la Escuela" (1982), stated the importance of working on texts that are interesting for children. He discovered that writing is an enjoyable activity if it has a purpose. He tried some strategies for developing his students' reflections while learning to write and read. The idea that he explored, as far back as the 1930's, was the use of newspapers in the classroom. Its amazing how that idea has crossed the ages, and time has shown that many teachers around the world have experimented with the benefits of using some kind of newspaper based activities with good results.

Figure 1: The cover of the San Agustin School Newspaper

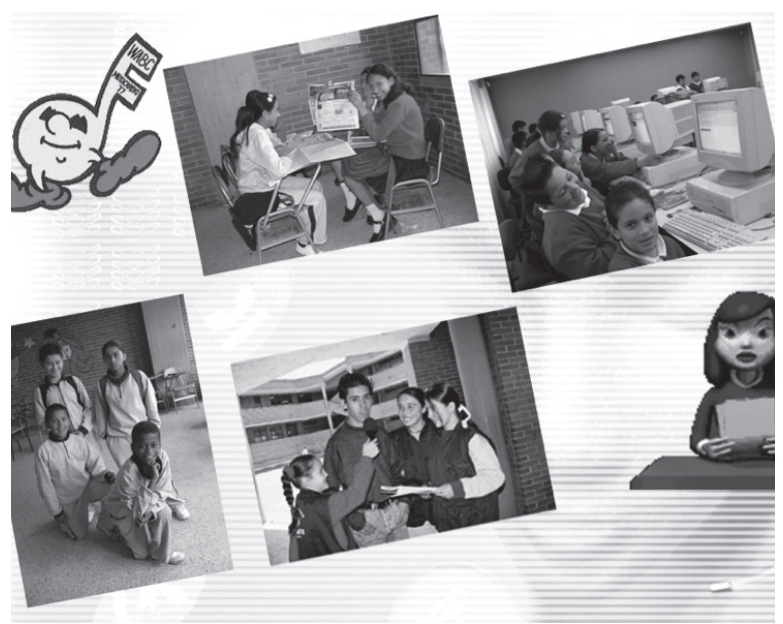


It is necessary, from his point of view, that in the school we deal with tasks that integrate all the disciplines and that have a clear purpose, well understood and agreed by the students. This links closely with the necessity to make the design of a curriculum more open and more flexible and that takes into account the time that the children require for the learning processes and the possibility to tailor the contents and the activities to the students, the school and the local contexts.

Taking into account these previous experiences, the languages department of San Agustin School started to work with the school newspaper in 2002. Almost 20 students (at least one from each grade) were involved in the first edition of "La Voz Agustina". With few resources, the first edition was one where each student had the opportunity to tell a story, to express themselves. These were done on blank pieces of paper that were then photocopied and glued together to be sold for 100 pesos.

Since that first edition, the students from that group worked very hard. Every six months they brought to the community the "big baby", the newspaper, full of language, pictures and stories. And of course, the English Zone was present in every edition. Classes started to change. Because of the newspaper, some children were recognised as the artists and others where recognised as the better writers. While they were learning they had the space to undertake their roles and tasks and share them with their families in homes, reflecting their pride and passion for their role with the newspaper.

Over time though, "La Voz Agustina" kids and teachers felt that something was still missing. Eventually, it was noticed that there were some machines and resources in the school that could enhance their job as communicators. By 2003, they founded the scholar radio station. As result, as described by López (2004) and confirmed by the transformation that the project had in San Agustín School: "Radio changed the script of the newspaper". The globalization of culture and the technological revolution is constantly changing everything towards the mass media.

\section{Waves of Change}

Within the spectrum of mass media, radio is the closest to natural human communication. Radio has its own language. In Balsebre's (1994) words, radio is defined as the "whole of all forms of sounds represented by the systems of expressive speech, music, sound effects and silence, whose meaning is determined by all the technical resources of expressive sound reproduction and the set of factors that characterize the process of perception and visual imagination of the listeners" In this context, radio, as with other mass media, can be an agent of education, because it helps to consolidate the knowledge and education of individuals in their free time.

Figure 2: The radio room at San Agustín School

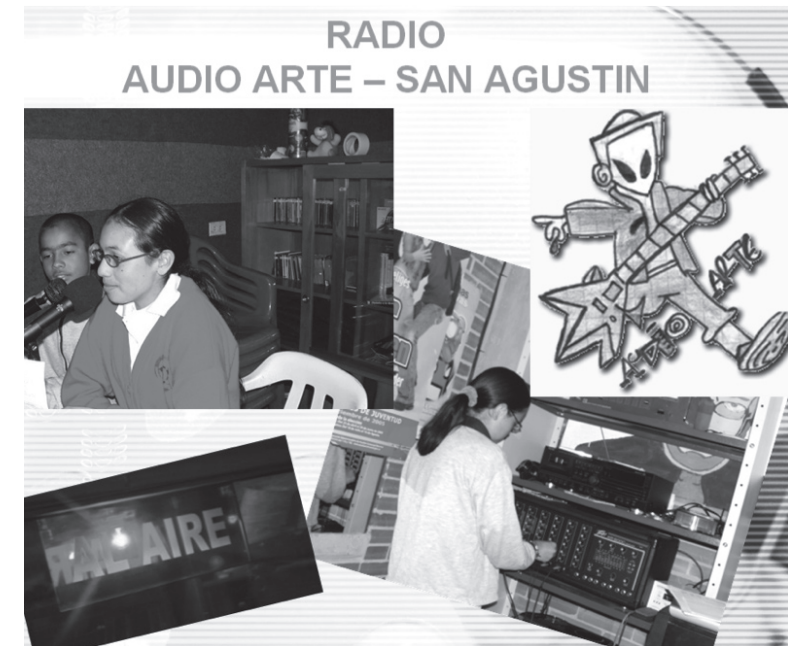

After a year of discussion, in a "call for participation" the name and logo were chosen. A $7^{\text {th }}$ grade student who wanted the radio came up with the name "Audio Arte". Once the radio was launched and established, eight $11^{\text {th }}$ graders were 
in charge of playing music and reading messages to the community during the mornings and some break times.

But, some teachers struggled with the practical aspects of ensuring that the radio was an effective and valuable experience for the students, so they started to look for help. They didn't know how to build a real pedagogical tool with the radio. For that reason it was necessary to ask for training courses. Universidad Minuto de Dios, Paulinas CCS, and Secretaría de Educación answered their questions. Teachers and students attended classes running for a year, learning how to deal with the connections, the mixer, and the microphones as well as how to construct and present material for radio broadcast. As Barbero (1987) stated, "more than a whole of new machines, of wonderful stuff, communication means a new sense, other new ways of feeling, of experiencing, of relate with the time and the space, new ways for recognize each other and join together" The students learnt how to use their voice not only to send romantic messages through the radio but also to listen to stories from the students' experiences. Stories that were told in many narrative ways: singing, performing characters, reading some verses.

While the voices started to be listened to the teachers also felt they needed to change the classroom activities. It became necessary to use a tape recorder during the classes to listen to the programs that the students were producing. It was time for reflection, because the stories told were really meant for the community, to be listened to, to inform and even to change the community.

In a conversation, Freire (1997) stated the following words which were the ones that inspired the work in the teachers and students group of radio "I dream of a society, being reinvented from the bottom to the top, where people have the real power to have a voice and not just the right to listen to. It is a dream that I find possible, but it demands a fantastic effort for creating it". Children's work/jobs, drugs, violence, ecology, sports, interests, sex, pregnancy of San Agustin girls, future careers, recycling, illnesses, musical favorite groups and topics such as those became the reason to go to the radio room everyday and plan and do a radio program.

Because of the impact that the experience had on the school, teachers and students began to dream of even more.

\section{Why Media Would Be The Chance?}

Comprehensive and innovative appropriation of mass media and ICT in schools may provoke a new classroom or practical dynamic producing changes to the established curriculum and pedagogical principles. The changes could provide previously unavailable opportunities for interactivity, enjoyment and social interchange where the students face new challenges in a real learning adventure, developing citizenship and values within the community.

Marshall McLuhan (1967) declared "the one who tries to find differences between education and diversion would show their total ignorance in both subjects", and this seems particularly true when referring to the mass media and ICT contents, to which students have constant access and where they get a wide quantity of information, apparently leading to deeper learning than that which takes place in the classrooms.

Sometimes the two discourses (the one from media and the one in the school) appear to be contradictory, but both of them could and should be reconciled by carefully reflecting with the generation exposed to both contents, building a mosaic of culture that requires a very critical attitude in order to integrate them in the same path.

The use of media and ICT in education would be an important component for the motivation 
of students and teachers with the opportunity to integrate the school with the environment, the neighborhood, the city and the country and of course with the world - gaining with this an analytic, critical and reflective spirit.

One new opportunity afforded by ICT is that or asynchronous collaborative or cooperative learning. Students can interact independent of time, and independent of location, commenting on questions or presented material, debating points or building material together. This new facility became a focus of activity at San Agustin School.

\section{Beyond Collaborative Learning}

Collaborative learning fosters individual accountability in a context of group interdependence in which students discover information and teach that material to their group and, perhaps, to the class as a whole. The teacher's role changes as King (1993) says "from sage on the stage to guide on the side." Although they learn in groups, the students are evaluated individually on the learning they have achieved".

Figure 3. Collaborative work - Learning together

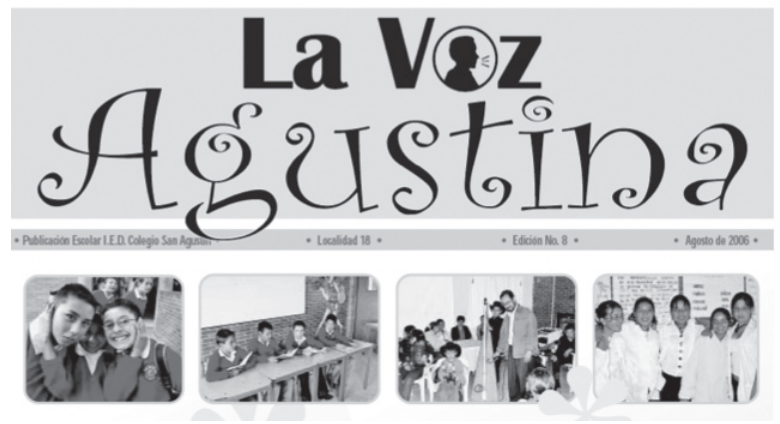

As Piaget (1928) pointed out, collaborative learning has a major role in constructive cognitive development. His theory is consistent with the other popular learning theories (Vygotsky, 1978) (Fox and Karen, 1990) in emphasizing the importance of collaboration. Piaget felt that interaction between peers is equally shared.
This contrasts adult-child or teacher-student interactions, where usually the former is in control and the latter characteristically follows what the former professes, thus not following his/her own natural learning process.

Working with media and seeking to reflect the prevailing culture of the students is an excellent way to get the students working in groups, collaboratively, cooperatively with clear goals, applying all the learned knowledge (from every area) and at the same time acquiring new practical knowledge. Also, as Manrique (2004) affirmed, the integration with other areas and with other generations promotes the dialogical communication and the democratization of the knowledge relationships.

This innovation also intended to encourage students' participation and to achieve some benefits that are the result of collaborative work in classrooms, for instance, to improve attendance because of their commitment to others in their group. Students in cooperative classrooms tend to have better attendance and increased participation, because they are contributing to the group and participating in class, students become more active learners.

\section{Images, Sounds and Stories Moving from One Culture to another one}

In addition to the support that ICT provides to enable students to collaborate asynchronously and remotely, and the pedagogic benefits of that approach, ICT enables students to work with not only the media involved in newspapers (words and images) and radio (sound and speech) but also video and other information types (GPS tracks and augmented realities), and linked information browsing supported by hypermedia techniques. The skills required to work with these media are diverse and extend the learning required by the students and the teaching required by the educators, as well as the means 
to have better preparation, extra time, and total dispositions for learning from new experiences. A new phase of the programme was established, known as "Education for Communication and Communication for Education" with the goal of exploring the cultural influences that media offer to the students involving the full spectrum of audiovisual media. Video and television have a component of pure visual expression just as painting and photography have, but they also have sounds like music or drama as theatre and literature have. This provides the school with a rich environment for enabling students to explore and face realities and expect innovation and change.

As the students became increasingly skilled in the production of audiovisual media, they could move on to reflect and be motivated to "read" their own visual productions, critiquing them against the contrasting images that they see daily in the "Agustina" community, always having the final goal of expressing and analysing presented contents.

\section{Spoken Language Learning Online: The Community Crossing the Language Sea}

Recognising the new practical and potential supported by ICT, it is recognized that there are some conditions associated with this interaction through the ICT as explained by Clavijo and Quintana (2004), and these become the social potential for education in the classrooms. As they stated, the presence, the proximity and the temporality stimulate new cognitive, affective, and social situations promoting collaborative learning as result of peer learning. It's a challenge to face the socio-cultural, economical, and technological reality that San Agustin has. From that, it is impossible to forget the mission that teachers have to offer analytical opportunities together with contents that make them and (of course) the students grow into critical, active and creative communicators.
Integration of ICT's in the school life is intended to reinforce the democratic processes, the communication inside the walls and help the active participation of the school in the building process of a "modern and humanistic city, including, solidarity and compromised with the Social State of Right" as our Development Plan (2004) states.

Applying hypermedia and hypertext in ICT's provides additional tools for education to consider historical and cultural diversity and the recognition of "the other one" a dialogical community of this contemporary world. "The cyberculture demands other ways for appropriating meaning" (Rueda, 2000)

Taking all the experiences of working with digital resources and various media explored above into account, San Agustin students realized they needed to explore new options. Computers, networks and their complex structure started to attract the attention of both students and teachers. It was necessary and essential to expand the range of action of the project urgently to exploit, in a managed and coherent way the potential offered by ICT. For that reason an agreement was established with teachers in 15 schools around the world where interactions and collaborative activities could be promoted within a community with common goals and a common spirit of innovation.

It quickly emerged that this community presented a powerful opportunity: an authentic and motivating reason to practice communication with peers in other places, including the use of their language. A central goal of this phase of the innovation therefore became to provide students with EFL literacy resources that were interesting, fun, and non-traditional. The hope was to build a community of storytellers/podcasters that increased their literacy skills and their fluency in different languages. For that reason it is 
interesting to apply what Stanley (2006) had expressed about the diverse possibilities for using podcasts in the language classroom, including as a supplement to textbook materials, as a source for authentic listening materials, and as a way for students to gain information on specific aspects of the language, such as idiomatic expressions or grammatical constructions.

Collaborative learning strategies were put in place to guide the classroom activity as students in different places interacted within the program "Crossing the Language Sea", involving local cohorts of students in Colombia, Chile, Argentina, USA, UK, Russia and Spain, facilitated by the Proyectemonos server hosted by the University of Dundee in the UK. The collaborative group work involving students in different locations was an integral part of the achievement of the learning goals of this experience. It was also intended to encourage students' participation and to achieve some benefits that are the direct result of collaborative work and peer learning in classrooms while participating in a virtual community.

Secondary school students can generally decode written familiar words. What they need to do at this stage is develop a variety of strategies for comprehending the meaning and message of the spoken texts related with their own daily life and environment. In order to do this, they need to think reflectively about their understanding of the audio and video materials, and be curious about the meaning of presented stories. Their level of curiosity helps determine their motivation for the task and their willingness to consider alternate strategies for listening comprehension and improving their skills (Bruner, 1966).

Meek (1991) suggests that "right from their earliest lessons children should be helped to reflect on what they have been doing and what they want to bring about." (Pg.67). If the students are asked what they were thinking about after for instance listening, the responses are very limited. However, if they are required to stop and think while listening; suddenly they have much more to say. As well, working with a partner stimulates a broader and deeper response than solitary class work.

The learning platform used for this activity facilitated the whole rich spectrum of expressing and communicating meaning through the various media encountered in the previous phases of the activities, As a result, students were motivated to not only seek to comprehend the meaning in the material produced by other students, particularly those who were expressing aspects that reflected very different cultural perspectives, but also to attempt to express themselves, even if this meant having to use a language other than their native language. The students sought to engage with completely different cultures, and happily grasped the opportunity to share their own identity and culture. Reflection on the meanings of the differences and similarities naturally followed.

\section{Conclusions and Reflections}

The internet and technology in general has given this generation of teachers a new and unique way to, "custom-tailor literacy activities to the interests, learning styles, and motivations of boys." (Booth, 2002).

Imagine different continents, a range of cultures and races, working together in a virtual space, where children and young people everyday share their media productions, listening to each other, understanding a foreign language, trying to communicate in the most comprehensible way, while at the same time learning together how to be the world citizens, how to understand their history and how to plan their future. This is what we are building towards, and in many respects where we are now.

This cultural and social interchange brought real life experiences of knowledge for the kids of 
the present (and will do for those in the future!), San Agustin School has been visited by teachers from other cultures and has exploited very important socialization spaces to tell the story: the story of how a wave changed the school.

The school and its teachers, in their daily work, should re-establish the position concerning the mass media and new technologies in a way that shows a real understanding and value for the extra classes experiences, the previous knowledge, the students wonderings, concerns, dreams or fantasies and most important of all, their daily life and the way they interact with, comprehend and critique media in their homes.

At the same time, school must be the first communicative space, where boys and girls build meanings, work together, and share with the adults the adventure of learning, respecting differences and developing skills in wise and independent decision making. It is the best space where the student's development and learning is in accordance with their ages/maturity, their possibilities and their interests, encouraging them to be the main characters of their lives, being responsible for their decisions and building a life path where they can imagine solutions and create new scenarios to transform their local communities and countries.

\section{References}

Barbero, M, J. (1987) Innovación tecnológica y transformación cultural, TELOS, N·9, Madrid;

Barbero, M. J. (1989) Identidad, comunicación y modernidad, Contratexto N· 4, Lima;

Booth, D. (2002). Even hockey players read: Boys, literacy and learning. Markham, ON: Pembroke.

Bruner, J. (1966). Toward a theory of instruction. Cambridge, MA: The Belknap Press of Harvard University Press.

Bruner, J. (1986). Actual minds, possible worlds. Cambridge, MA: Harvard University Press.

Clavijo A, and Quintana A. (2004). Maestros y Estudiantes Escritores de Hiperhistorias. Universidad Distrital Francisco José de Caldas.
Cooper, J. David. (1997). Literacy, literature and learning for life. http://www.eduplace.com/rdg/res/literacy. html

Emler, N. (2001) Gossiping, in W.P. Robinson and H. Giles (Eds.) "The New Handbook of Language and Social Psychology", pp.317-340. Chichester, England, UK: John Wiley and Sons Ltd.

Freinet, C. (1982). Modernizar la Escuela. Barcelona, Laia, 1982.

Freire, P. (1972). "Education: domestication or liberation," in Prospects, Vol.II, No. 2 (Summer). Reproduced in Lister, I. 1993. Deschooling - a reader. Cambridge: Cambridge University Press.

Freire, P. and Macedo, D. (1987). Literacy: Reading the word and the world. South Hadley, MA: Bergin and Garvey

Fox, B. and Karen (1990). Collaborative cognition. Report from Linguistics Department, University of Colorado, Boulder.

King, A. (1993). From Sage on the Stage to Guide on the Side, College Teaching, 41 (1).

Manrique, L. (2005) La Prensa. En Comunicación y Escuela. Orientaciones para promover la incorporación usos y apropiación de los medios de comunicación en las instituciones educativas de Bogotá. Serie: Estudios y Avances. SED Bogotá. Colombia.

McLuhan, M. (1967). The Medium is the Massage, Penguin Books, Estados Unidos.

Meek, M. (1991). On being literate. London: The Bodley Head.

Piaget, J (1928) The language and thought of the child. New York: Harcourt.

Rueda R (2000) Apropiación Social de las Tecnologías de la Información. Cyberciudadanías Emergentes. http://www.flacso.org.ec/docs/sfinternet.pdf

Schank, R.C. (1990) Tell me a story: a new look at real and artificial memory. New York, New York, USA: Scribner's, Macmillan Publishing Company.

Schank, R.C. and Abelson, R.P. (1995) Knowledge and memory: The real story, in Wyer, R.S. (Ed.) Knowledge and Memory: The Real Story, pp.1-85. Hillsdale, New Jersey, USA: Lawrence Erlbaum Associates, Publishers.

Stanley, G. (2006). Podcasting: Audio on the Internet Comes of Age. TESL-EJ, 9(4).

Vygotsky, L.S. (1978) Mind in society (ed. by M. Cole, V. John-Steiner, S. Scribner, and E. Souberman), Cambridge, MA: Harvard University Press. 